\title{
Tényleg édes és dicső a hazáért meghalni?
}

Akár hálás is lehetnék egyes embereknek, politikusoknak, hogy annyit foglalkoznak a haza kérdésével. Meg a nemzetével. Pedig úgy vagyok vele, hogy ha nem kérdezik, tudom, mi a hazám, és tudom, azt is, hogy magyar vagyok, de ha megkérdik, el kell gondolkodnom.

Tavaly például megcsináltattam a DNS-tesztemet, és arra jöttem rá, hogy a DNS-em a hazám, a genetika világpolgára vagyok. Kiderült: 40 százalékban kelet-európai vagyok, 40 százalékban nyugat-európai - ezen belül 12,5 százaléknyi ír, walesi és skót -, 20 százalék meg balkáni, mindezeken belül meg akad még másfél százaléknyi zsidó vér avagy DNS is bennem. A géntérkép szerint pedig a három nagy halmaz közös metszete éppen arra a Vajdaságra esik, ahonnan történetesen származom.

A hálám persze nem feltétlen amiatt, hogy egyesek úgy vélik, a hazáért érdemes feláldozni az életünket. Bár általában a másokéra gondolnak, a sajátjuk túl drága nekik, hogy odaadják a fennkölt célért. Többnyire meg csak akkor esik le nekik a tantusz, ha a saját gyermeküket hozzák haza a frontról cinkkoporsóban.

Az egykori Jugoszláviában születtem, éppen nagykorú lettem, amikor végül szó szerint is berobbant a jugoszláv válság. Még 19 éves sem voltam, amikor a jugoszláv-szerb hadseregben koptattam bakancsom talpát, ekkor már háborús idők jártak. A tisztjeink lelkesítő beszédeket tartottak arról, hogy meg kell védeni az ellenségtől (vagyis körülbelül mindenkitől) a hazát: Jugoszláviát - ami már szétesett -, vagy Szerbiát, vagy a hadsereget, vagy valamit, a becsületünket, a büszkeségünket s a többi. Valójában ők sem tudták, hogy miért harcolunk. Az erkölcsi nevelésért felelős őrnagy egyébként macedón volt, jobban, vagyis rosszabbul törte a szerb nyelvet, mint én, és neki segédkeztem a temetések intézésében. Az első búcsúztató szöveget még a biztonsági kapitány diktálta, ő egyébként vajdasági magyar volt, legalábbis a neve alapján, de dél-bánátiként egy kukkot sem beszélt már magyarul, legalábbis így tett. Gyakran kérdezgette, hogy ha a szerb és a magyar hadsereg egymással harcolna, melyik felet választanám? A vállamat vonogattam, remélhetőleg ilyesmire nem kerül sor, mondtam. Azóta is Woody Allennel vallom, hogy a legközelebbi háborúban túsz szeretnék lenni, mindegy, melyik oldalon.

Ha nincs a háború - ami a hazával való foglalatoskodás végeredménye lett, röviden összefoglalva -, alighanem bölcsész lettem volna a Vajdaságban, magyar

A szerző szociológus, a Társadalomtudományi Kutatóközpont Kisebbségkutató Intézet munkatársa. E-mail: Horvath.Gyorgy@tk.hu 
irodalmár, mondjuk. De akkor, 1990 tájékán úgy éreztem, valami itt nem stimmel, és emiatt fordultam a szociológia felé, hogy talán megértem, mi történik. Majd Budapestre kerültem az egyetemre, és lettem végül kutatóféle. Háromszor emigráltam Magyarországra: először diákként, aztán menekültként az újabb, NATO-val folytatott háború miatt, végül öt évig újra Bácskában éltem és dolgoztam, de a munka végett megint Budapesten kötöttem ki - igazi migráncs vagyok. Azóta is sokat ingázom, és a Vajdaságban is vizsgálódtunk a kollégákkal, hogy például az ottani magyar fiatalok mit tartanak a hazájuknak meg a nemzetüknek. Mint kiderült, a legtöbben Szerbiát és Magyarországot is, illetve a szerbet és a magyart is, de valójában a regionális identitásuk a legerősebb: a vajdasági magyar. Ök, akik még nem is éltek a délszláv válság idején, vagy akkortájt születtek, mintha szintúgy belefáradtak volna a kérdésbe. És oly sokan ingáznak közülük is a határon át, vagy éppen az emigráláson gondolkodnak, hogy jól tudják: a haza fogalmával túl sokat manipulálnak a fenn lévők, és végül azok járják meg, akik lenn vannak.

A hazafiság persze az irodalom egyik, ha nem a legfennköltebb témája, különösen a költők imádják a pátoszos megközelítést, bár akadnak jócskán ironikus feldolgozások is. Noha ez nem irodalomóra, most Danilo Kišt emelném ki, a magát az utolsó jugoszláviai írónak vallót, aki egyébként magyar zsidó apától és egy montenegrói szépségkirálynőtől származott, és magyar költőket is fordított. Egyébként kisgyerekként Magyarországon bújtatták, így élte túl a holokausztot. A holtak enciklopédiája címü kötetében akad egy novella, amelynek eredeti címe: Slavno je za otadžbinu mreti, és ezt magyarul Mily dicső a hazáért halni címen jelent meg, ami pedig Horatius szállóigévé vált sorának - “dulce et decorum est pro patria mori” - rövidített verziója, az eredeti tehát úgy hangzik, hogy „Édes és dicső a hazáért meghalni."

Danilo Kiš - akinek az identitása többes kötődésű volt, akárcsak az enyém, és végül párizsi emigrációban halt meg - viszont éppen arra jutott, hogy a hazáért meghalni aligha édes, még ha a vér elvileg édes is. Hovatovább a dicsőség is kétes. Ha már valamit tehetünk a hazáért, akkor inkább éljünk érte. Attól pedig különösen óvakodjunk, hogy másoknak megmondjuk, miért érdemes meghalni. 